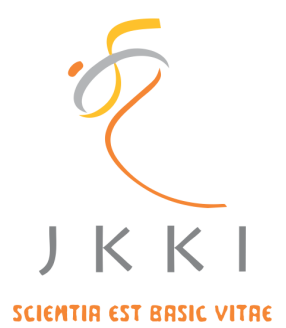

Jurnal Kedokteran dan Kesehatan Indonesia

\author{
Indonesian Journal of Medicine and Health
}

Journal homepage: https://journal.uii.ac.id/JKKI

\title{
Prolonged severe acute respiratory syndrome of Corona Virus-2 positive with polymerase chain reaction: A case report
}

\author{
Linda Rosita*1, Rahma Yuantari ${ }^{1}$, Budi Mulyono ${ }^{2}$, Umi Solekhah Intansari² ${ }^{2}$ Ingesti Bilkis Zulfatina ${ }^{3}$ \\ ${ }^{1}$ Patology Clinic Department, Faculty of Medicine, Universitas Islam Indonesia, Yogyakarta, Indonesia \\ ${ }^{2}$ Patology Clinic Department, Faculty of Medicine, Public Health and Nursing, Universitas Gadjah Mada, Yogyakarta, \\ Indonesia \\ ${ }^{3}$ Ngemplak Public Health Center, Sleman, Indonesia
}

Case Report

\begin{tabular}{|c|c|}
\hline & ABSTRACT \\
\hline ARTICLE INFO & \multirow{10}{*}{$\begin{array}{l}\text { COVID-19 continues to spread across the world, with more than } 60 \text { million } \\
\text { confirmed cases in } 220 \text { countries. Since March } 11,2020 \text {, WHO announced } \\
\text { the COVID-19 outbreak as a pandemic. Impacts caused by COVID-19 are } \\
\text { not only on the health sector but also economic, social, and political sectors. } \\
\text { In a diagnosing process, the SARS-CoV-2 PCR results for swab specimen } \\
\text { are a gold standard in determining confirmed COVID-19 cases. Previously, } \\
2 \text { repeated results of negative SARS-CoV-2 PCR become criteria of being } \\
\text { recovered from COVID-19. Therefore, based on the latest guidelines from } \\
\text { the Indonesian Ministry of Health revised on July } 13 \text { th } 2020 \text {, patients with } \\
\text { no symptoms, mild to moderate symptoms, and severe symptoms are } \\
\text { declared to be recovered if the patients meet the requirements of finished } \\
\text { periods of isolation based on a doctor's assessment. Confirmed cases } \\
\text { with severe or critical symptoms are specially declared with one negative } \\
\text { result of the PCR test plus three days without showing any symptoms. This } \\
\text { case study discussed a } 52 \text {-years-old woman diagnosed with COVID-19. } \\
\text { PCR test for this patient had been conducted } 11 \text { times during } 64 \text { days of } \\
\text { treatment, and its results turned to be always positive, failing to fulfil the } \\
\text { discharge criteria. Therefore, it needs to determine causes of prolonged } \\
\text { positive PCR results and impacts of clinical condition of the patients, and } \\
\text { prognosis of the patients. }\end{array}$} \\
\hline & \\
\hline & \\
\hline $\begin{array}{l}\text { gold standard, } \\
\text { prolonged positive } \\
\text { SARS CoV-2 }\end{array}$ & \\
\hline *Corresponding author: & \\
\hline DOI: 10.20885/JKKI.Vol11.Iss3.art12 & \\
\hline Istory: & \\
\hline eceived: June 11, 2020 & \\
\hline & \\
\hline $\begin{array}{l}\text { Copyright @2020 Authors. } \\
\text { This is an open access article } \\
\text { distributed under the terms } \\
\text { of the Creative Commons At- } \\
\text { tribution-NonCommercial } 4.0 \\
\text { International Licence (http:// } \\
\text { creativecommons.org/licences/ } \\
\text { by-nc/4.0/). }\end{array}$ & \\
\hline
\end{tabular}

COVID-19 terus menyebar ke seluruh dunia, dengan lebih dari 60 juta kasus terkonfirmasi di 220 negara. Sejak 11 Maret 2020, WHO mengumumkan wabah COVID-19 sebagai pandemi. Dampak yang ditimbulkan oleh COVID-19 tidak hanya pada bidang kesehatan tetapi juga pada bidang ekonomi, sosial, dan politik. Dalam proses diagnosa, hasil PCR SARS-CoV-2 untuk spesimen usap merupakan gold standard dalam menentukan kasus COVID-19 yang terkonfirmasi. Sebelumnya, setidaknya 2 hasil berulang PCR negatif SARS-CoV-2 menjadi kriteria sembuh dari COVID-19. Oleh karena itu, dari pedoman terbaru Kementerian Kesehatan RI yang direvisi pada 13 Juli 2020, pasien tanpa gejala, gejala ringan hingga sedang, dan gejala berat dinyatakan dapat pulih jika pasien memenuhi persyaratan menyelesaikan masa isolasi berdasarkan pada penilaian dokter. Kasus yang dikonfirmasi dengan gejala parah atau kritis secara khusus dinyatakan dengan satu hasil negatif dari tes PCR ditambah tiga hari tanpa menunjukkan gejala apa pun. Kasus di bawah ini membahas seorang wanita berusia 52 tahun yang didiagnosis dengan COVID-19. Tes PCR untuk pasien ini telah dilakukan 11 kali selama 64 hari pengobatan dan hasilnya selalu positif, tidak memenuhi kriteria kepulangan. Oleh karena itu, perlu ditentukan apa penyebab dari hasil PCR positif berkepanjangan dan, dampak dari kondisi klinis pasien, serta prognosis pasien lebih rendah atau tidak. 


\section{INTRODUCTION}

Coronavirus Disease 2019 (COVID-19) is a highly contagious disease caused by a new coronavirus found in the late 2019. The virus has never been identified before in humans. It was previously known as 2019 novel corona virus (2019-nCoV), revised to severe acute respiratory syndrome coronavirus 2 (SARS$\mathrm{CoV}-2$ ). Coronavirus is a large family of viruses that cause illness ranging from mild to severe symptoms. Two types of coronaviruses are known to cause severe symptoms such as Middle East Respiratory Syndrome (MERS) and SARS. ${ }^{1}$

Clinical appearance of COVID-19 characterizes broad spectrums that fluctuate from asymptomatic to severe symptoms. ${ }^{2}$ Until today, more than 14 million people have been infected with the virus. The mortality rate has reached 612,443 people in more than 200 countries. ${ }^{3}$ Indonesia have the highest mortality rate in Asia and it continues to increase. More than 500,000 have been infected with the virus and the death cases have reached more than 16,000 people. ${ }^{4}$ In addition, impacts caused by COVID-19 are not only on the health sector but also economic, social, and political sectors.

Patients are examined to obtain accurate data to make decisions in dealing with the COVID-19. Especially, the most reliable test to confirm the disease known as Polymerase Chain Reaction (PCR) has been also used as discharge criteria in $4^{\text {th }}$ edition of Panduan Pencegahan dan Pengendalian Coronavirus (COVID-19) (Guidelines of Prevention and Management for Covid 19) by Indonesian Ministry of Health until on July $13^{\text {th }} 2020$, that was revised at some adjustments. ${ }^{1}$

Indonesian Ministry of Health had released guidelines related to COVID-19 since early cases found in Indonesia. Previously, 2 repeated results of negative SARS-CoV-2 PCR became the criteria of being recovered from COVID-19. Therefore, from the latest guideline revised on July $13^{\text {th }} 2020$, patients with no symptoms, mild to moderate symptoms, and severe symptoms are declared to be recovered if the patients meet the requirements of finished period of isolation based on a doctor's assessment. Confirmed cases with severe or critical symptoms are specially declared with one negative result of the PCR test plus three days without showing any symptoms.

In some patients including the patient in this case report, they had no ongoing symptoms, but they still had prolonged positive PCR results. Therefore, according to previous guidelines, they cannot be discharged until the results are negative. However, today the discharge becomes possible since the latest guideline allows it. Hence, it needs to determine causes of prolonged positive PCR results and impacts of the clinical condition of the patients, and prognosis of the patients.

\section{CASE DESCRIPTION}

$\mathrm{Z}$, a 52-year-old woman, who had travelled from Jakarta for 4 days admitted that she had come to an emergency unit at JIH Hospital with a chief complaint of dyspnoea. The patient also complained of fever, cough, and sore throat. Contact histories with positive, probable, and suspect patients of Covid 19 were denied. She worked in a non-medical facility, and there was no contact history with a pet. On physical examination, her blood pressure was 125/78 $\mathrm{mmHg}$, her pulse rate was 98 beats per minute, her respiratory rate was 26 times per minute, and her body temperature was $38.0 \mathrm{oC}$. The patient's body mass index (BMI) was 29. Based on lung examination in the left lung, there was weakening bronchovesicular, and in both lungs there was rhonchi sound.

The chest X-ray results stated there was pneumonia in the right lung. Laboratory hematologic examination result was entirely within normal limits for haemoglobin (13.5 g/ dl), white blood count (WBC) $(7.140 \mu \mathrm{L})$, platelet count (PLT) $(230.000 / \mu \mathrm{L})$, absolute neutrophil $(4.49 / \mu \mathrm{L})$, absolute monocyte $(0.49 / \mu \mathrm{L})$, absolute lymphocyte (/ $\mu \mathrm{L} 2.12)$, and Neutrophilto-Lymphocyte Ratio (NLR) (2.1). Rapid tests for SARS CoV-2 antibodies, IgM, and IgG were both reactive. PCR results for nasopharynx swabs were positive for SARS-CoV-2.

Management taken for the patient was 
hospitalization in an isolation ward. Her drugs include Intravenous Fluid Drops (IVFD) Hydromel (16 drops per minute), Levofloxacin (750mg/24 hours), Hydroxychloroquine (2x200mg), Oseltamivir (2x75mg), Paracetamol (1gr intravenous if needed), Pantoprazole (1 ampoule/12 hours), Levocof syrup (3xCth II), Vitamin C (1000mg/24 hours IV), Dalfarol (2x1), Cavit D3 (1x1). Good communication, information, and education about impacts and potential complications were also provided to this patient and her family. After 10 days of treatments, the clinical condition of the patient became better, butreverse-transcriptase PCR (RT$\mathrm{PCR}$ ) results for SARS-CoV-2 were all still positive until the 11th swab. This patient underwent a total of 64 days of the treatment period. She was then diagnosed with a prolonged-positive RTPCR SARS CoV-2. The prognosis of this patient was dubia ad malam.

\section{DISCUSSION}

COVID-19 is an infection disease, caused by the novel coronavirus SARS-CoV-2, previously known as 2019-nCoV. Coronaviruses are zoonotic meaning that they originate from animal sources and transmit to a human population. Coronaviruses (CoVs) are a large family of viruses that cause illnesses ranging from the common cold to more severe diseases such as MERS and SARS. SARS-CoV-2 is a novel coronavirus that has not been previously identified in humans. Moreover, with implementation of strong travel restrictions, international travel by a large number of individuals contaminated by the SARS-CoV-2 has resulted in a spread of the virus worldwide. ${ }^{5}$

The diagnosis of COVID-19 is based on clinical manifestations, laboratories, and radiology findings. The clinical manifestation's classifications are as follows: (1) mild, with fever, respiratory tract symptoms, and imaging shows of pneumonia; (2) moderate, meeting any of the following: a) respiratory distress, respiratory rate $\geq 30$ beats $/ \mathrm{min} ; b$ ) in the resting state, mean oxygen saturation with $\leq 93 \%$; c) arterial blood oxygen partial pressure/oxygen concentration with $300 \mathrm{mmHg}(1 \mathrm{mmHg}=0.133 \mathrm{kPa})$; (3) severe, one of the following conditions: a) a respiratory failure occurs and requires mechanical ventilation; b) a shock occurs; c) ICU admission is required for combined organ failures. ${ }^{6}$

All suspected 2019-nCoV infection patients were taken upper respiratory throat (nasopharynx) for swab samples at admission and stored in virus transport medium, which was transported to Balai Besar Teknik Kesehatan Lingkungan dan Pengendalian Penyakit

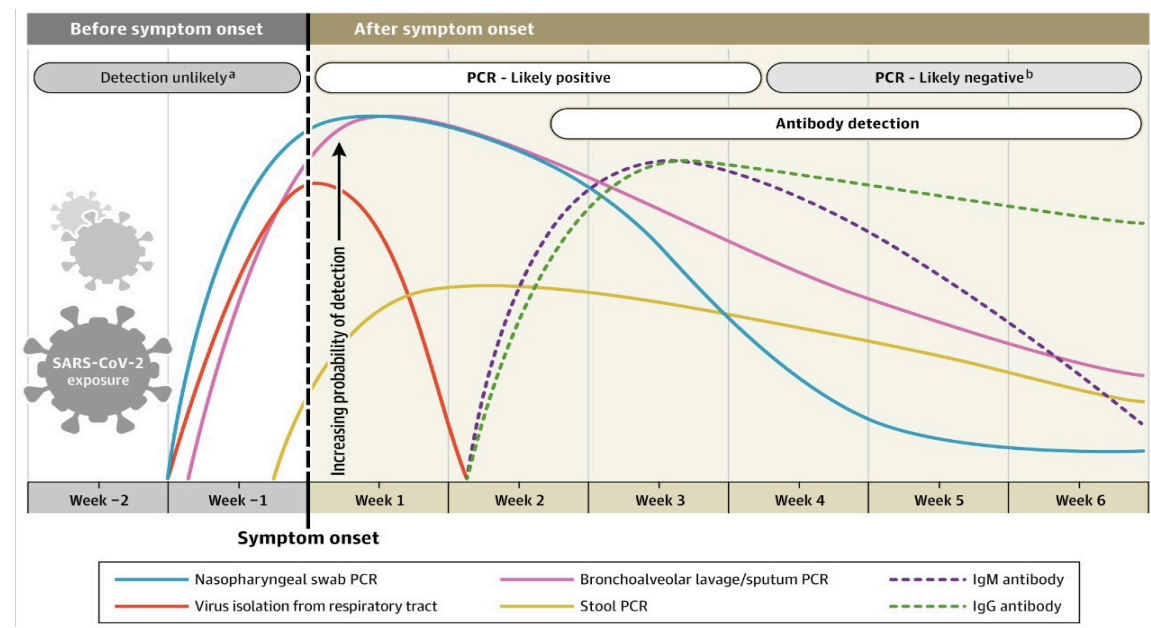

Figure 1. Detection of PCR and antibodies of COVID-19.' (Sethuraman et al., 2020) a. Detection only occurs if patients are followed up proactively from the time of exposure. b. It seems more likely to register a negative than a positive result by PCR of a nasopharyngeal swab. Reproduced with permission from [Interpreting diagnostic tests for SARS-CoV-2. 2020.323(22):2249-2251]. CopyrightC2020 American Medical Association. All rights reserved. 
(BBTKLPP) for laboratory diagnosis with PCR. The evolvement of diagnostic tests for SARS$\mathrm{CoV}-2$ is continuing to find a better understanding of their nature and interpretation. In a study, Sethuraman et al. (Figure 1) describes how to interpret types of diagnostic tests used for SARS$\mathrm{CoV}-2$ which can be classified into polymerase chain reaction (PCR) and IgM and IgG enzymelinked immunosorbent assay (ELISA).Therefore, the most used and reliable test for diagnosing COVID-19 has been a RT-PCR test performed by using a nasopharyngeal swab, although other specimens can also be used, including bronchoalveolar lavage/sputum and stool. In the RT-PCR, cycle threshold or $\mathrm{Ct}$ is the number of replication cycles required to produce a fluorescent signal, which means lower Ct values represent higher viral RNA loads. ${ }^{7}$

In an individual with symptomatic COVID-19, a viral RNA from a nasopharyngeal swab as measured by $\mathrm{Ct}$ is detectable on day 1 of symptom until its peak in the first week from the symptom onset. The $\mathrm{Ct}$ values less than 40 are clinically reported as PCR positive and start to decline by week 3 . After that, it will subsequently become undetectable. However, a positive PCR result represents only the detection of RNA and doesn't indicate the presence of the viable virus. Timelines of PCR positivity from other specimens are different. In sputum specimens, PCR positivity may decline more slowly and may still be positive even though nasopharyngeal swabs are negative. PCR positivity in stool remained positive within 4-11 days and its persistence was found to be similar to PCR positivity in sputum. ${ }^{7}$

Another method to identify the infection of SARS-CoV-2 by an indirect method is using measurements of antibodies as a host immune response. The most sensitive serological marker to diagnose COVID-19 is a total of antibodies which begin to increase from the second week of symptom onset. Immunoglobulin M and G (IgM and IgG) ELISA with higher levels occur in the second and third week of illness, even though they already have been found positive from day 4. Persistence and duration of protection by the antibodies remain unknown. ${ }^{7}$
According to WHO, the management of COVID-19 is classified based on the level of the patient's symptoms, such as mild, moderate, severe, acute respiratory distress syndrome (ARDS), and septic shock. For general management, the patient must be isolated to contain virus transmission. In patients with mild COVID-19, uses of symptomatic treatments, such as antipyretics, adequate nutrition, and appropriate rehydration is recommended. In patients with a moderate symptom, antibiotics should not be used unless there is a clinical suspicion of bacterial infection. Older people and children $<5$ years of age provide empiric antibiotics for possible pneumonia. Close monitoring of patients is for disease progression in case of need of medical care escalation.

For severe COVID-19 patients, they must be isolated in a health care area with pulse oximeters, functioning oxygen systems and disposables, single-use, oxygen delivering interfaces, such as a nasal cannula, venturi mask, and mask with reservoir bag. Oxygen supplementation should be used when patients show emergency signs or have oxygen saturation $\left(\mathrm{SpO}_{2}\right)<90 \%$. Close monitoring for signs of clinical deterioration, such as a progressive respiratory failure and shock is recommended. Management of critical COVID-19 which develops ARDS is by preparing prompt recognition of a progressive acute hypoxemic respiratory failure by providing an oxygen/ventilator support. For patients with septic shock, the treatment should be focused to maintain mean arterial pressure (MAP) and lactate levels. ${ }^{1}$

Occurrence of IgM and IgG antibodies would likely be reactive on week 2 and have a positive swab test result earlier on week 1 of symptom onset. However, this patient had reactive IgM and IgG antibody test results and a positive swab test result in week 1 . This could happen since symptoms felt by the patients were subjective, so there might be some symptoms that were not considered as "symptom". In addition, there were slight differences between one study and others. For example, a study presented that reactive IgM results were found in day 0 of symptom onset, 
whereas reactive $\operatorname{IgG}$ was in day $5 .^{8}$

After 10 days of treatments, the clinical condition of the patient became better, but RTPCR results for SARS-CoV-2 were all still positive until the 11th swab. This patient underwent a total of 64 days of a treatment period. This patient was then diagnosed with a prolongedpositive RT-PCR SARS CoV-2.

Due to many shortcomings of the diagnosing process of COVID-19, which mainly relies on the PCR test, many patients cannot be detected because of false-negative results tested by using insufficient rapid detection kits. The early warning score is then introduced as an effective and simple multi-parameter diagnostic tool. This newly-developed Early Warning System (EWS) was a tool for early and relatively accurately warning of positive COVID-19 patients. In this patient, she has a score of 6 from fever, age, Tmax, and meaningful respiratory symptoms. ${ }^{9}$

Table 1. Early Warning Score (10)

\begin{tabular}{|c|c|c|c|}
\hline No. & Parameter* & Assessment & Score \\
\hline 1. & Sign of pneumonia on CT Scan & Yes & 5 \\
\hline 2. & History of close contact with COVID-19 confirmed patient & Yes & 5 \\
\hline 3. & Fever & Yes & 3 \\
\hline 4. & Age & 44 years or more & 1 \\
\hline 5. & Gender & Male & 1 \\
\hline 6. & Maximal temperature from illness onset to first hospital admission (Tmax) & $37.8^{\circ} \mathrm{C}$ or more & 1 \\
\hline 7. & $\begin{array}{l}\text { Meaningful respiratory symptoms (including cough, expectoration, } \\
\text { dyspnea) }\end{array}$ & 1 or more & 1 \\
\hline 8. & Neutrophil-to-lymphocyte ratio (NLR) & 5.8 or more & 1 \\
\hline
\end{tabular}

*Highly suspected COVID-19 if total score were 10 or more

Based on 766 patients' analysis from National Centre for Infectious Diseases, percentages of PCR-negative results increase from $68 \%$ on day 21 to $88 \%$ on day 28 and to $95 \%$ on day 33. Meanwhile, $5 \%$ of patients, PCR- positivity extends to a month or becomes longer. It is important to note that viral RNA detected by PCR doesn't indicate the infectiousness or viable virus. ${ }^{11}$

Additionally, a Ct value is used to identify the viral load or viral RNA amount. A high Ct value indicates a low viral load/viral RNA amount and vice versa. Nevertheless, as noted above, the detection of viral RNA doesn't necessarily mean the presence of infectious or viable viruses. In a study, when Ct value was 30 or higher, no viable virus has been found, with the condition of being able to culture virus, which can't be isolated or cultured after day 11 of illness. These data mean that even though viral RNA detection may persist in some patients, its detection represents noninfectious and non-viable viruses. ${ }^{11}$
Viral shedding is a process when a virus replicates and is released into the environment, which means the virus is very infectious. COVID-19 has its first week of symptom to have a high degree of viral shedding. It is confirmed by its viral RNA intermediates (viral subgenomic messenger Ribonucleic Acid or sgRNA) which only present in actively infected cells. After 10-11 days of symptom, sg RNA declined. Infectious virus was cultured from throat and lung specimen, but none after day 8 was found when high viral loads were detected by PCR. ${ }^{11}$

The infectiousness of COVID-19 previously occurred with the onset of symptoms rapidly declines by the end of the first week of illness. In asymptomatic positive COVID-19 patients, the infectiousness remains unknown; however, they may have similar viral shedding patterns. Meanwhile, viral RNA is detected mostly until 2-4 weeks from the onset of the disease, but some persist to a month or even until day $60 .{ }^{11}$

Similar case reports are rarely found, but 
some patients had recurrent positive PCR results which may be related to this case because of false-negativity of PCR results that may occur. In a study of 287 discharged COVID-19 patients, it was found that $11.5 \%$ patients had recurrent PCR positivity after discharged. It was found that the risk factors were female gender, elevated serum creatinine level, and increased serum SARS-CoV-2-specific IgG antibody titer. ${ }^{12}$

In another study of 4 patients with confirmed COVID-19, it revealed that they had 2 consecutive negative PCR test results, but the time onset to recovery ranged from 12 to 32 days. After 5-13 days, their PCR test results were positive. These findings meant that some patients still might be the virus carriers. Even though there might be false-negative PCR test results, they were qualified with the previous criteria of discharge, so the quarantine was discontinued at that time. ${ }^{13}$ In a case report of two patients in China, the patients had positive PCR test results, and after some days of quarantine, the PCR test results became be negative. The next day, the PCR test result turned back positive. A reasonable explanation for these findings is difficult to find. The virus can be detected in the upper respiratory tract at early infection, but it will be more likely to appear in the lower respiratory tract and other locations when the disease has progressed. ${ }^{14}$

This is related to a policy adopted in many countries about the patient's discharge and deisolation policy by using repeated PCR tests. Previously in Indonesia, two negative PCR results in 24 hours apart can change a status of a patient, from positive to recovered-COVID-19. Moreover, when a clinical condition is good, but the RT- PCR SARS-CoV-2 results have not been negative, a patient has not been declared cured. ${ }^{1}$ These conditions lead us to allow for revised discharge criteria. Beside absence of RNA detection which takes months, discharge criteria should be based on data of infectiousness time while also takes consideration of clinical and public health aspects. Therefore, health resources can be focused on testing persons with acute respiratory symptoms and suspected
COVID-19 in early stage, so that the management can be conducted earlier. ${ }^{11}$

Revised guidelines of Indonesian Ministry of Health have stated new regulations. The first is changes of PDP and ODP term into suspect patients. The second is about a patient's discharge from the hospital: patients with no symptoms, mild to moderate symptoms, and severe symptoms are declared to be recovered if the patients meet the requirements of finished period of isolation based on a doctor's assessment. The isolation period of these patients takes 10 days from the symptom onset plus at least 3 days without symptoms. Confirmed cases with severe or critical symptoms are specially declared with one negative result of the PCR test plus three days without showing any symptoms. When there is no PCR test available, the discharge criteria are same as other levels of the symptoms. Asymptomatic patients are stated to be recovered 10 days after the positive result. ${ }^{15}$

Earlier than Indonesia, WHO changed the criteria on June $17^{\text {th }}, 2020$. The criteria are same as the guidelines of Indonesian Ministry of Health. Reasons for the changes of criteria were the prolonged viral RNA detections, insufficient testing capacity, prolonged viral shedding around the limit of detections so that the result was initially negative followed by a positive result. ${ }^{17}$

However, the priority is about stopping the transmission especially when the viral shedding is high around the first week. The high transmission was also found near and just before the onset. Then, the secondary attack rate decreases as the symptoms progress.16 From a study in 5 Asian countries, it was found that $14.9 \%$ of case samples were work-related. Only some countries established lockdown policies so that a working aspect is a variable that affects the transmission rate in each country. In this study, five occupation groups with most cases were healthcare workers (22\%), drivers and transport workers (18\%), services and sales workers (18\%), cleaning and domestic workers $(9 \%)$ and public safety workers $(7 \%) .{ }^{17}$ 


\section{CONCLUSION}

Positive SARS-CoV-2 RT-PCR results can persist up to 64 days even with a better clinical condition, but this does not mean that the virus is still viable and infectious. Discharge criteria had been revised based on the clinical assessments of the patients. However, stopping the transmission must become a priority step to eradicate the COVID-19.

\section{CONFLICT OF INTEREST}

The author declares that there is no conflict of interest.

\section{ACKNOWLEDGEMENTS}

The authors express the greatest respect and sincere wishes to the front-line workers struggling against the COVID-19.

\section{REFERENCES}

1. Kemenkes. Pedoman pencegahan dan pengendalian coronavirus disease (covid-19) revisi ke-4 1. 2020;Edisi Ke-4.

2. Meo SA, Al-Khlaiwi Th, Usmani AM, Meo AS, Klonoff DC, Hoang TD. Biological and epidemiological trends in the prevalence and mortality due to outbreaks of novel coronavirus COVID-19. Journal Of King Saud University. 2020;32(April):2495-9.

3. WHO. Covid-19 Outbreak Situation. 2020.

4. Tugas G. Infogravis Covid-19 (7 Juni 2020). 2020.

5. Saxena SK. Coronavirus Disease 2019. Vol. 2019. 2019

6. Liu J, Liu Y, Xiang P, Pu L, Xiong H, Li C, et al. Neutrophil-to-Lymphocyte ratio predicts severe illness patients with 2019 Novel Coronavirus in the early stage. 2020;807.

7. Sethuraman N, Jeremiah SS, Ryo A. Interpreting diagnostic tests for SARS-CoV-2. Journal of the American Medical Association. 2020;323(22):2249-2251.

8. Robin Augustine, Suvarthi Das, Anwarul Hasan, Abhilash S, Shaheen Abdul Salam, Priya Augustine, et al. Rapid antibody-based COVID-19 mass surveillance: Relevance, challenges, and prospects in a pandemic and post-pandemic. World Jour- nal of Clinical Medicine. 2020;9: 1-26.

9. Song C-Y, Xu J, He J-Q, Lu Y-Q. COVID-19 early warning score: A multi-parameter screening tool to identify highly suspected patients. medRxiv. 2020:1-22.

10. Susilo A, Rumende CM, Pitoyo CW, Santoso WD, Yulianti M, Sinto R, et al. Coronavirus disease 2019: Tinjauan literatur terkini. Jurnal Penyakit Dalam Indonesia. 2020;7(1):45-67.

11. NCID. Position statement from the national centre for infectious diseases and the chapter of infectious disease physicians. National Centre for Infectious Diseases. 2020;(May):1-5.

12. Wang K, Liu D. Clinical characteristics of COVID-19 patients with recurrent PCR positivity After hospital discharge. 2020:1-15.

13. Lan L, Xu D, Ye G, Xia C, Wang S, Li Y, et al. Positive RT-PCR Test Results in Patients Recovered From COVID-19. 2020;

14. Xing Y, Mo P, Xiao Y, Zhao O, Zhang Y, Wang F. Post-discharge surveillance and positive virus detection in two medical staff recovered from coronavirus disease 2019 (COVID-19), China , January to February 2020. 2020;25(10):2000191.15. K e menterian Kesehatan RI. Pedoman pencegahan dan pengendalian Coronavirus Disease (COVID-19) Revisi 5. 2020;1-214.

16. Cheng H-Y, Jian S-W, Liu D-P, Ng T-C, Huang W-T, Lin $\mathrm{H}-\mathrm{H}$. Contact tracing assessment of COVID-19 transmission dynamics in Taiwan and risk at different exposure periods before and after symptom onset. JAMA Internal Medicine. 2020;1-8.

17. Lan F-Y, Wei C-F, Hsu Y-T, Christiani DC, Kales SN. Work-related COVID-19 transmission in six Asian countries/areas: A follow-up study. PLoS One. 2020;1-11. 